\title{
COMPARISON OF ALGEBRA LEARNING OUTCOMES USING REALISTIC MATHEMATICS EDUCATION (RME), TEAM ASSISTED INDIVIDUALIZATION (TAI) AND CONVENTIONAL LEARNING MODELS IN JUNIOR HIGH SCHOOL 1 MASOHI
}

\author{
Anderson Leonardo Palinussa \\ Universitas Pattimura, Indonesia
}

\begin{tabular}{l} 
Article Info \\
\hline Article history: \\
Received Jul 9, 2020 \\
Revised Sep 5, 2020 \\
Accepted Sep 6, 2020 \\
\hline
\end{tabular}

\section{Keywords:}

Learning outcomes, Realistic Mathematics

Education,

Team Assitsed

Individualization,

Conventional,

Algebra

\begin{abstract}
The study aims to examine the application of the Realistic Mathematics Education (RME), the Cooperative Learning Model Team Assited Individualization (TAI) type and conventional learning models on algebra. The population in thIS study were all eighth grade SMPN 1 Masohi. The type of this study is an experimental research design with quasi experimental research. Instruments in this study using the test results, analyzed using ANOVA test and further tests using Tukey's HSD test. From the analysis of these study obtained data: (1) Based on the normality test results obtained sig. X1 (RME Learning Model) of 0.976, X2 (Cooperative Learning Model TAI Type) of 0.889 and X3 (Conventional Learning Model) of 0.906. (2) Based on the one-way ANOVA calculation with the SPSS 20.0 program, obtained a significance value of 0.003 . (3) There are significant differences in algebra learning outcomes between classes using the RME learning model, the cooperative learning model TAI type and conventional learning model, and (4) The algebra learning outcomes of students used the RME learning model are higher than the students that are used cooperative learning models TAI type and the students that used conventional learning model.
\end{abstract}

Copyright (C) 2020 IKIP Siliwangi. All rights reserved.

\section{Corresponding Author:}

Anderson Leonardo Palinussa,

Department of Mathematics Education,

Universitas Pattimura

Jl. Ir. M. Putuhena, Poka, Tlk. Ambon, Maluku 97233, Indonesia

Email: apalinussa@yahoo.com

\section{How to Cite:}

Palinussa, A. L. (2020). Comparison of algebra learning outcomes using realistic mathematics education (RME), team assisted individualization (TAI) and conventional learning models in junior high school 1 Masohi. Infinity, 9(2), 173-182.

\section{INTRODUCTION}

The world of education at the lowest level up to the highest level is basically played by mathematics as a complementary science in all disciplines. In addition, mathematics is very useful to be applied in terms of life, so it becomes a provision that must be required by students. 
The difficulty of students in working on mathematical problems is inseparable from the teacher's role. According to Clarke \& Roche (2017) teachers have an important role in the learning process. The low number of Indonesian students in the 2015 PISA results reflects that learning by teachers still emphasizes the ability to read, write and count.

In fact, although mathematics is a subject that plays an important role in education, there are still students who do not master mathematics. Because students continue to be used as learning objects in a series of learning activities, while the teacher becomes the center of learning. Ratumanan (2015) says that student activities in class are not involved in teaching mathematics. Because the role of the teacher is made more dominant to learn material that is not the teacher's job. This causes students to be less active in learning, so understanding concepts about student mathematics is very lacking and poor students learning outcomes.

The process of learning mathematics in the classroom found a variety of problems including, the teacher still dominates the learning process and when the teacher explains that only some students pay attention well, while other students are busy telling stories and when given questions students only apply the formula given and student activity is not yet visible in the learning process so the learning becomes meaningless. In addition, teachers only use conventional learning models, so learning in the classroom tends to be monotonous which causes students to be bored and lazy to learn, and result in weak understanding of student material, especially for material that is considered difficult. This resulted in decreased student learning outcomes.

To overcome the problems that have been raised, it is necessary to choose an appropriate learning model and can be a solution to improve the quality of learning. The Realistic Mathematics Education (RME) learning model and the Team Assisted Individualization (TAI) type of cooperative learning model can be applied to increase understanding and increase student creativity.

The Realistic Mathematics Education (RME) learning model is one of a series of classroom learning programs designed with the aim of building students' ability to know things that have not been learned through student activities. Mathematical concepts become the basis for students to find them in learning mathematics guided by the teacher. Problem solving in the form of contextual problems becomes the principle of students discovering the mathematical concept itself. Formal mathematical knowledge is obtained by students by modeling the contextual problems they face while learning. In addition, everyday human activities become mathematics learning materials that are designed with the aim of achieving the goals of mathematics learning (Gravemeijer, 1994).

One of the cooperative learning models that can be used is the Team Assisted Individualization (TAI) type. TAI has the meaning that students in groups or teams formed heterogeneously when they have a goal to understand the material provided by the teacher must be assisted by individuals who have good learning abilities. Meanwhile, according to (Siregar, Budiyono, \& Slamet, 2018) TAI has a rationale that is to achieve the ability and achievement of students to adapt to differences in individual abilities.

The TAI type of cooperative learning model is a learning model designed to solve problems in teaching programs, for example in terms of student learning difficulties individually and can help students be more active in the classroom because students will work together between groups in solving the given problems, students also interact with each other, help each other and complement each other. Thus every student who has a low ability when assisted by students who have high abilities have the hope to improve their abilities. With this learning model, the key to success in achieving the mathematics learning goals to be achieved is to adapt students to one another.

Based on the background above, the problems to be investigated and discussed in this study are (1) Is there a difference in student learning outcomes taught with the RME 
learning model, the TAI type of cooperative learning model, and the conventional model on the algebraic arithmetic operations material. (2) Which learning model is superior to RME learning model, TAI type Cooperative learning model and conventional learning models on algebraic arithmetic operations material.

\section{METHOD}

The type of this research used the experimental research. The research design is quasi experimental research because the researcher cannot control the variables outside the research that the researcher did not expect. The variables contained in this study are $X_{1}$ : Student learning outcomes in mathematics taught with the RME learning model, $\mathrm{X}_{2}$ : Student learning outcomes in mathematics taught with cooperative learning model TAI type and $\mathrm{X}_{3}$ : Student learning outcomes in mathematics taught with conventional learning models. The learning tools in this study are in the form of learning implementation plan (RPP), student worksheets (LKS), and learning materials.

Determine the population to be the beginning of this study and choose a sample of the existing population. The population in this study were all students of eighth grade of Junior High School 1 Masohi, Central Maluku District. The sample selection is done by purposive sampling technique, which is the technique of determining the sample with certain considerations (Bidgood, Hunt, \& Jolliffe, 2010). There are three classes chosen by researchers as research samples and obtained the first class as an experimental class 1 using the RME learning model, the second class as an experimental class 2 using a TAI type of cooperative learning model, and the third class as a control class using a conventional learning model.

Data obtained from the results of research in the form of quantitative data. The quantitative data then tested to answer the hypotheses that have been formulated by researchers in accordance with established test procedures. Quantitative data were obtained from even semester test results and post test results. Data analysis of the results of even semester tests using Microsoft Excel 2013 software was carried out to find out that the three experimental classes had almost the same average values. The aim is to ensure that at least there is no difference in the initial capabilities of the three groups. While the post test data analysis uses SPSS (Statistical Product and Service Sulation) version 20. for windows in order to find out accept $\mathrm{H}_{0} / \mathrm{H}_{1}$.

\section{RESULTS AND DISCUSSION}

\subsection{Results}

This study began by using the results of the even semester tests to determine the experimental class 1, experimental class 2 and the control class and to determine differences in learning outcomes used the post test. After comparing it turns out that even semester 2018/2019 test results between classes eighth grade-1, eighth grade-6, and eighth grade-7 are relatively the same as shown in Figure 1. 


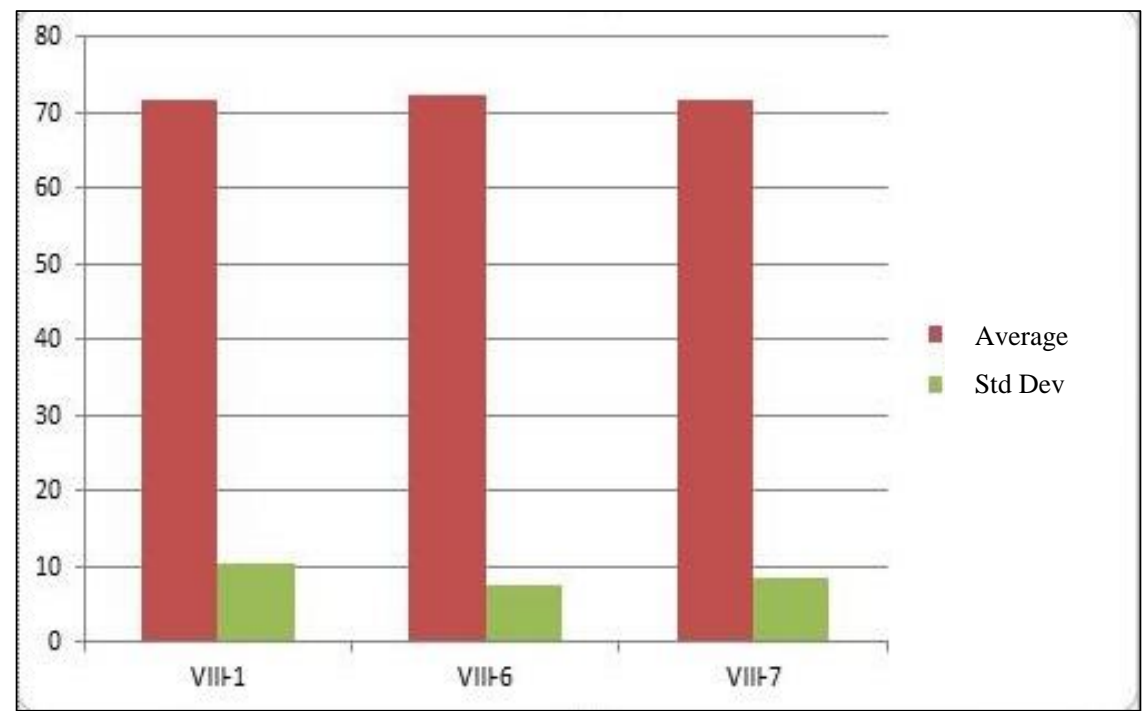

Figure 1. Average daily repeat value

From the average semester test scores (Figure 1), the experimental class 1 is eighth grade-7 with an average of 71.6154, experimental class 2 is eighth grade- 1 with an average of 71.8333, and the control class is eighth grade-6 with an average 72.333. Data normality and homogeneity of data were tested before using the ANOVA test. The prerequisite test which includes the normality test uses the chi-square test and homogeneity test using the $\mathrm{F}$ test. To find out whether the data is normal or not normal, a chi-square calculation is done for the control class and the experimental classes and the results are as shown in Table 1.

Table 1. Normality test results

\begin{tabular}{lcc}
\hline \multicolumn{1}{c}{ Class } & Sig. & $\boldsymbol{\alpha}$ \\
\hline Experiment 1 (RME) $\left(\mathrm{X}_{1}\right)$ & 0.976 & \\
Experiment 2 (TAI) $\left(\mathrm{X}_{2}\right)$ & 0.889 & 0.05 \\
Control (Conventional Learning) $\left(\mathrm{X}_{3}\right)$ & 0.906 & \\
\hline
\end{tabular}

Data decision making is normal if Asymp Sig. (2-tailed) is greater than the level of significance. Based on Table 1 obtained sig. $\mathrm{X}_{1}=0.976, \mathrm{X}_{2}=0.889$ and $\mathrm{X}_{3}=0.906$ which is greater than the significance level of 5\% (0.05), so it can be stated that all data are normal. Then the variance homogeneity test is performed.

To find out that the ability of students in a homogeneous population, two or more variances were used in common using the Levene Test (See Table 2).

Table 2. Homogeneous variance test

\begin{tabular}{lcc}
\hline \multicolumn{1}{c}{ Class } & Sig. & $\boldsymbol{\alpha}$ \\
\hline Experiment 1 (RME) $\left(\mathrm{X}_{1}\right)$ & & \\
Experiment 2 (TAI) $\left(\mathrm{X}_{2}\right)$ & 0.654 & 0.05 \\
Control (Conventional Learning) $\left(\mathrm{X}_{3}\right)$ & & \\
\hline
\end{tabular}


Table 2 show that Calculation of the similarity of two or more variances using the levene test shows the value of sig. greater than $5 \%(0.05)$ is $0.654>0.05$, from the test criteria for the levene test is accept $\mathrm{H}_{0}$ if $\mathrm{F}_{\text {count }}<\mathrm{F}_{\text {table }}$ and reject $\mathrm{H}_{0}$ if $\mathrm{F}_{\text {count }}>\mathrm{F}_{\text {table, }}$ it can be concluded that the variance of the three data groups is experimental 1, experimental 2 and control class is homogeneous because $\mathrm{H}_{0}$ is accepted which is $0.95<3.12$.

From the test scores of learning outcomes and calculations of the mean, standard deviation, one-way ANOVA, for the experimental 1, experimental 2 and control class the following results were obtained (See Table 3).

Table 3. ANOVA calculation

\begin{tabular}{ccccccc}
\hline $\begin{array}{c}\text { Source of } \\
\text { Variation }\end{array}$ & Df & $\begin{array}{c}\text { Sum of } \\
\text { squares }\end{array}$ & MK & F count & F $_{\text {table }}$ & Decision \\
\hline Total & 74 & 18286.207 & - & & & \\
Between groups & 2 & 2740.756 & 1370.378 & 6.347 & 3.12 & $\mathrm{~F}_{\text {count }}>\mathrm{F}_{\text {table }}$ \\
In Group & 72 & 15545.451 & 215.909 & & & \\
\hline
\end{tabular}

Based on the ANOVA one way calculation used SPSS 20.0 program, a significance value of (0.003) was obtained, meaning that the value of sig. is less than $5 \%(0.05)$, it can be concluded that there are differences in learning outcomes of the three learning models. Table 3 show that $\mathrm{F}_{\text {count }}>\mathrm{F}_{\text {table }}$ is obtained $(6.347>3.12)$ then $\mathrm{H}_{0}$ is rejected or there are differences in the learning outcomes of eighth grade students of Junior High School 1 Masohi who are taught using the Realistic Mathematics Education (RME) learning model, the Team Assisted Individualization (TAI) of cooperative learning model and the conventional learning model in the Operations of Algebra.

To determine a better learning model among the three learning models used, the average value of student learning outcomes from the three learning models can be considered which can be presented as follows in Figure 2.

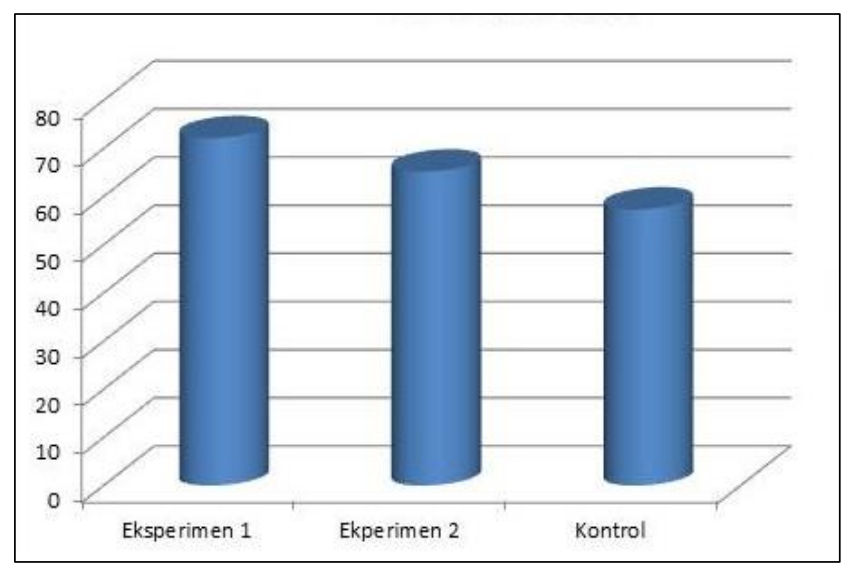

Figure 2. The average value of the three groups after treatment was given

Figure 2 show that the average value of the highest student learning outcomes is the class taught by the Realistic Mathematics Education (RME) learning model (72.1332). Then the cooperative learning model Team Assisted Individualization (TAI) Type (65.2020) and the lowest is the conventional learning model (57.3356). Furthermore, to find out a better learning model among the three learning models used, then using a follow-up test or socalled after ANOVA analysis using Tukey's HSD (See Table 4). 
Table 4. Average differences between groups

\begin{tabular}{cccc}
\hline & $\mathrm{X} 1$ & $\mathrm{X} 2$ & $\mathrm{X} 3$ \\
\hline $\mathrm{X}_{1}$ & - & 6.9312 & 7.8664 \\
$\mathrm{X}_{2}$ & 6.9312 & - & 7.6904 \\
$\mathrm{X}_{3}$ & 14.7976 & 7.8664 & - \\
\hline
\end{tabular}

Interpret HSD values by comparing the average differences between groups with the results of HSD calculations. Based on the Tuckey's HSD test results obtained the value of $\mathrm{HSD}=9.9926$. Test the difference $\mathrm{X}_{1}$ and $\mathrm{X}_{2}=7.4537$. Obtained from the difference between the average $X_{1}$ and $X_{2}$ ie $(72.1332-57.3356)$ then $X_{1}=X_{2}$ because $6.9312<9.9926$, Test the difference $X_{1}$ and $X_{3}=14.7976$. Obtained from the difference between the average $X_{1}$ and $X_{3}$ ie $(72.1332-57.3356)$ then $X_{1} \neq Y$ because $14.7976>9.9926$, Test the difference $\mathrm{X}_{2}$ and $\mathrm{X}_{3}=7.8684$ Obtained from the difference between the average $\mathrm{X}_{2}$ and $\mathrm{X}_{3}$ ie $(65202$ - 57.3356) then $X_{2}=X_{3}$ because $7.8664<9.9926$.

Based on Tuckey's HSD calculation (See Table 4), the average value of the three classes is experimental $1\left(\mathrm{X}_{1}\right)$ which has a higher average number so it can be stated that the learning model that is superior among the three learning models is the Realistic Mathematics Education (RME) learning model.

\subsection{Discussion}

In the class taught by the Realistic Mathematics Education (RME) learning model, at the beginning of the learning the teacher provides stimulus in the form of material using contextual examples, so that students can better understand the material provided through these examples. And then by following the steps in the RME learning model the teacher guides students to be able to understand the steps of learning. Although initially the students still looked confused, with the teacher's guidance the students were then able to understand the steps in the RME learning model well. After students get an explanation of what RME is and the steps of the RME learning model, students who have been sitting in groups begin to look busy with the material to be completed in the group.

RME has superior potential compared to conventional and TAI learning models in improving mathematics learning outcomes. In RME students are trained to develop reasoning and logical abilities. Mathematics learning through RME is very relevant to students in dealing with daily problems so that students can interact with the teacher continuously to solve problems. Various studies with RME in Indonesia explore the extent to which RME can be utilized and stimulate improved learning process (Sembiring, Hadi, \& Dolk, 2008). During the learning process takes place students are also required to better understand the material by solving questions in the worksheet in groups. This causes a sense of responsibility, mutual respect and mutual assistance in the group during the learning process.

The RME learning model itself is a learning model that can structure the level of student understanding so that students can relate information that has just been obtained with existing material with the cognitive structure they have. According to Gravemeijer (1994) and Afriansyah (2016), there are three main principles in RME, namely: (a) guided reinvention and progressive mathematization); (b) didactical phenomenology; and (c) a selfdeveloped model. The first phase guided reinvention, which students should be given the 
opportunity as a society to find a process similar to the process in which mathematics is found. During the learning process, students independently have the opportunity to build their own mathematical knowledge. In the second stage of didactic phenomenology, a situation that is relevant to the topic of mathematics is created so that it can be applied to be investigated in learning. Therefore, it is also necessary to balance the types of applications or methods that must be anticipated in learning by the teacher. The aim of the phenomenological inquiry is to find problem situations in which a specific approach can be generalized. Another aim is to find situations that give rise to a paradigmatic solution procedure. The third stage is a self-developed model. Self-developed models play an important role in bridging the gap between limited informal knowledge and formal mathematical knowledge. This model was developed by the students themselves. Through mathematical generalization and formalization, this model is developed by students to aid mathematical reasoning (Sumirattana, Makanong, \& Thipkong, 2017).

The results of this study are relevant to the results of research (Batlolona et al., 2019) which found that RME has very good effect on improving the mathematics learning outcomes of junior high school students. RME allows teachers and students to connect the context of abstract learning material to be concrete. It is easier to solve contextual problems that students encounter in their daily lives with RME. Therefore, RME assists teachers in designing learning that is relevant to the needs of students in real-life contexts. Reality concept is a context of known children's knowledge in their lives, and then becomes components of thinking scheme. The scheme components connect various mathematical contexts and concepts. Related to this situation, creative thinking can involve various dimensions of knowledge in every stage of cognitive thinking process. Thus, reality and intertwinement as RME principles can be used to encourage someone's learning outcomes. The real learning concept is the context of the child's knowledge that is known in his life, then becomes a component schema of thought. Schema components connect various mathematical contexts and concepts. Associated with in this situation, thinking process can involve various dimensions of knowledge in every stage of thinking process. Thus, reality and linkages as the principles of RME can be used to encourage thought processes so that learning outcomes increase (Muhtarom, Nizaruddin, Nursyahidah, \& Happy, 2019; Nuraida \& Amam, 2019; Sitorus \& Masrayati, 2016; Umbara \& Nuraeni, 2019).

Student learning outcomes are much improved with RME compared to STAD and conventional learning due to an increase in learning activities as well. Learning that is real and in accordance with real-world conditions, encourages students to increase learning activities (Arsaythamby \& Zubainur, 2014). This happens because students become curious about the topic they are studying when it is related to real conditions. Students arouse curiosity to reveal how the solution to the problems they face. In addition, students experience learning on their own, so they feel the importance of learning and understand that RME helps them in learning. On the other hand, RME can make learning memorized meaningful because students try to connect information that is already in their minds with information that will be obtained so as to enhance student understanding because it contains a summary of concepts and material relationships in the cognitive structure of students (Clarke \& Roche, 2017). This awareness is very motivating for an increase in learning outcomes compared to TAI and conventional learning.

In the class taught by the TAI type of cooperative learning model the teacher only works as a facilitator who is ready to help groups or individuals who need help. The results of individual work will be brought into their respective groups to be discussed and discussed in groups. All group members are responsible for the entire answer that is done. In this learning model there is no competition between students in groups because students work together to complete the given task and students also respect each other's different ways of 
thinking, students not only expect help from the teacher, but also motivated to learn accurately fast on all material. The results of group learning are compared with other groups to get awards in the form of praise from the teacher. This type of TAI cooperative learning places more emphasis on group appreciation. Of the five groups in this TAI class, the fourth group was given credit for their work as the super group or the best group while the first, second, third and fifth groups were given credit for their work as a good group. Then each student in the group is given an evaluation in the form of a quiz (fact test).

In the other hand, the selection of the TAI model as a learning model is felt to be accordance with the existing problems. The use of TAI is the use of a very simple learning model and is able to provide understanding concepts to students so easily that it becomes a solution for students in learning difficult material. In TAI learning, students are required to actively solve problems given by the teacher individually or in groups. The groups formed in the learning of TAI consist of students who have high, medium and low abilities making it easier for students to discuss. Students who lack understanding can ask students who understand better, especially the group leader (Ikhsanudin, 2014). Alimuddin (2017) state that the TAI model had a significant influence on the mathematics learning outcomes of seventh grade students at Bungap Satoro Middle School by 13.7\%. From the results of the research conducted above it can be concluded that the Team Assisted Individualization model can improve learning outcomes and motivation.

In classes taught by conventional learning models, at the beginning of learning the teacher conveys the material to be learned and conveys the learning objectives. After that, during the learning process takes place the teacher dominates the learning process while the students only pay attention and record what is explained by the teacher. The teacher explains the material in stages, then gives examples of questions, after that gives the opportunity for students to ask questions and respond back to what students are asking. Conventional learning is more oriented towards achieving curriculum goals so that it ignores efforts to instill concepts that are deep and relevant to student needs (Leasa \& Corebima, 2017). However, if there are no questions from students, the teacher will continue the material. Then the teacher provides a summary and assignments to complete. In addition, during the learning process only certain students pay attention, while other students don't pay attention to what the teacher says. This is because the learning model used is more centered on the teacher, so students only accept what is conveyed by the teacher which results in a less active learning process. In line with that Aziz \& Hossain (2010) argues that the conventional learning model or lecture method that focuses students' full attention on the teacher so that only teachers are active here, while students are only subject to listening to the explanation presented by the teacher.

\section{CONCLUSION}

Based on research that has been done and discussion of research results, it can be concluded that there is a difference in the learning outcomes of eighth grade students of Junior High School 1 Masohi who are taught using the RME learning model, the cooperative learning model Team Assisted Individualization (TAI) type and the conventional learning model. Other than that, the superior model used to teach algebraic operations is the RME learning model. RME has a positive impact on student learning outcomes when compared Team Assisted Individualization (TAI) and the conventional learning model. 


\section{REFERENCES}

Afriansyah, E. A. (2016). Makna Realistic dalam RME dan PMRI. Lemma, II(2), 96-104. https://doi.org/10.22202/j1.2016.v2i2.578

Alimuddin, H. (2017). Pengaruh Keaktifan Belajar Siswa Melalui Penerapan Model Pembelajaran Kooperatif Tipe Team Assisted Individualization (TAI) Terhadap Hasil Belajar Matematika Siswa Kelas Vii Smp Negeri 4 Satap Bungoro. HISTOGRAM: Jurnal Pendidikan Matematika, $1(1), \quad 61$. https://doi.org/10.31100/histogram.v1i1.182

Arsaythamby, V., \& Zubainur, C. M. (2014). How a Realistic Mathematics Educational Approach Affect Students' Activities in Primary Schools? Procedia - Social and Behavioral Sciences, 159, 309-313. https://doi.org/10.1016/j.sbspro.2014.12.378

Aziz, Z., \& Hossain, A. (2010). A comparison of cooperative learning and conventional teaching on students' achievement in secondary mathematics. Procedia Social and Behavioral Sciences, 9, 53-62. https://doi.org/10.1016/j.sbspro.2010.12.115

Batlolona, J. R., Laurens, T., Leasa, M., Batlolona, M., Kempa, R., \& Enriquez, J. J. (2019). Comparison of Problem Based Learning and Realistic Mathematics Education to Improve Students Academic Performance. Jurnal Pendidikan Progresif, 9(2), 185197. https://doi.org/10.23960/jpp.v9.i2.201921

Bidgood, P., Hunt, N., \& Jolliffe, F. (2010). Assessment Methods in Statistical Education: An International Perspective. In Assessment Methods in Statistical Education: An International Perspective. https://doi.org/10.1002/9780470710470

Clarke, D., \& Roche, A. (2017). Using contextualized tasks to engage students in meaningful and worthwhile mathematics learning. Journal of Mathematical Behavior, (September), 1-14. https://doi.org/10.1016/j.jmathb.2017.11.006

Gravemeijer, K. (1994). Educational development and developmental research in mathematics education. Journal for Research in Mathematics Education, 25(5), 443471. http://doi.org/10.2307/749485

Ikhsanudin, I. (2014). Pengaruh Penggunaan Pembelajaran Kooperatif Tipe Stad Berbantuan Wingeom Terhadap Kemampuan Pemecahan Masalah Geometri Siswa Sma. AKSIOMA Journal of Mathematics Education, 3(1), 40-49. https://doi.org/10.24127/ajpm.v3i1.380

Leasa, M., \& Corebima, A. D. (2017). The effect of numbered heads together (NHT) cooperative learning model on the cognitive achievement of students with different academic ability. Journal of Physics: Conference Series, 795(1), 012071. https://doi.org/10.1088/1742-6596/795/1/012071

Muhtarom, M., Nizaruddin, N., Nursyahidah, F., \& Happy, N. (2019). The effectiveness of realistic mathematics education to improve students'multi-representation ability. Infinity Journal, 8(1), 21-30. https://doi.org/10.22460/infinity.v8i1.p21-30

Nuraida, I., \& Amam, A. (2019). Hypothetical learning trajectory in realistic mathematics education to improve the mathematical communication of junior high school students. Infinity Journal, 8(2), https://doi.org/10.22460/infinity.v8i2.p247-258

Ratumanan, T. G. (2015). Learning and Learning and the Factors that Affect it. Surabaya: Unesa University Press. 
Sembiring, R. K., Hadi, S., \& Dolk, M. (2008). Reforming mathematics learning in Indonesian classrooms through RME. ZDM, 40(6), 927-939. https://doi.org/10.1007/s11858-008-0125-9

Siregar, I. I., Budiyono, B., \& Slamet, I. (2018). Team Assisted Individualization (TAI) in Mathematics Learning Viewed from Multiple Intelligences. Journal of Physics: Conference Series, 1108(1), 012073. https://doi.org/10.1088/1742$6596 / 1108 / 1 / 012073$

Sitorus, J., \& Masrayati, M. (2016). Title page Students ' creative thinking process stages : implementation of realistic mathematics education. Thinking Skills and Creativity, 22, 111-120. https://doi.org/10.1016/j.tsc.2016.09.007

Sumirattana, S., Makanong, A., \& Thipkong, S. (2017). Using realistic mathematics education and the DAPIC problem-solving process to enhance secondary school students ' mathematical literacy. Kasetsart Journal of Social Sciences, 38(3), 307315. https://doi.org/10.1016/j.kjss.2016.06.001

Umbara, U., \& Nuraeni, Z. (2019). Implementation of realistic mathematics education based on adobe flash professional CS6 to improve mathematical literacy. Infinity Journal, 8(2), 167-178. https://doi.org/10.22460/infinity.v8i2.p167-178 